\title{
Reproductive response of Calanus helgolandicus. II. In situ inhibition of embryonic development
}

\author{
M. Laabir ${ }^{1, *}$, S. A. Poulet ${ }^{1}$, A. Ianora ${ }^{2}$, A. Miralto ${ }^{2}$, A. Cueff $^{1}$ \\ 'Station Biologique de Roscoff, CNRS et Université Paris VI, F-28682 Roscoff, France \\ ${ }^{2}$ Stazione Zoologica Anton Dohrn, Villa Comunale, I-80121 Naples, Italy
}

\begin{abstract}
Seasonal variations in the viability of Calanus helgolandicus eggs are reported in coastal waters off Roscoff, in the western English Channel. In situ hatching success was highly variable with $>50 \%$ amplitude between minimum and maximum values. Highest production of abnormal embryos and nauplii was recorded during spring and midsummer. Examination of the faecal pellet contents produced by wild females revealed that they were feeding on extremely diversified prey, depending on the time of year. During spring-summer phytoplankton blooms, diatoms were always the dominant food, the remains of which were found in the faeces. During the rest of the year, non-diatom diets constituted the most important fraction of the prey. Inhibition of embryonic development was attributed to the ingestion of diatoms by wild females, based on laboratory experiments demonstrating similar low hatching success and anomalies when females were fed dense diatom cultures. The failure to statistically establish a straightforward correlation between the concentration of chlorophyll $a$ and variations of hatching success in the field is discussed with reference to experimental data.
\end{abstract}

KEY WORDS: Calanus helgolandicus Diatom Inhibitıon Egg · Viability

\section{INTRODUCTION}

Until now, the problem of poor egg quality in copepods and the causes inducing low hatching success have not been closely investigated in the field. In fact, naturally occurring, inviable eggs were usually considered as dead, unfertilized or dormant (Marshall \& Orr 1952, Parrish \& Wilson 1978, Watras \& Haney 1980). Ianora et al. (1992) showed that remating was probably not the only factor controlling egg viability in copepods.

Good egg quality, leading to vigorous nauplii, determines variability in the recruitment rate of natural populations (Kjørsvik et al. 1990, Pepin \& Myers 1991. Ianora \& Poulet 1993) and enhances the ability of the first developmental stages to survive. Quantifying viable eggs, which represent the net gonadic growth of adult females, is important since it determines the fate of secondary production (Poulet et al. 1995a). It also indirectly influences fish recruitment, since the first naupliar stages of copepods are important prey of fish larvae (Cushing 1975, Turner 1984a).

\footnotetext{
•E-mail: laabir@sb-roscoff.fr
}

Egg quality is linked to the recent past feeding history of females in their natural environment. In fact, the lag time necessary for the conversion of food to eggs in several species is minimal ( 24 to $92 \mathrm{~h}$; Tester \& Turner 1990) when compared to the total life of the females ( $>2$ mo for Calanus helgolandicus) and their reproductive activity ( $\geq 30 \mathrm{~d}$ in $C$. helgolandicus; Paffenhöfer 1975).

In the laboratory, diatoms have been shown to have a detrimental effect on egg viability (Ianora \& Poulet 1993, Poulet et al. 1994, 1995b, Ianora et al. 1995a, Miralto et al. 1995) either when algae were fed to adults at saturation levels, or when freshly spawned eggs were exposed to diatom extracts.

In the field, lanora \& Poulet (1993) reported that in wild Temora stylifera a succession of low and high egg viability coincided with periods of high and low diatom biomass, respectively. Anomalies in naturally occurring Centropages typicus eggs were reported earlier, although their causes were unknown (Ianora et al. 1992). In both cases, correlations between in situ chlorophyll a (chl a) concentration and hatching success were not significant, implying that a direct link between this food characteristic and variations in egg 
viability does not exist, or is not easy to establish in the field.

The objective of the present study was to verify if the major diatom blooms occurring in coastal waters off Roscoff were being fed upon by Calanus helgolandicus females and could subsequently induce either a significant decrease in hatching success of eggs, or abnormal development in embryos and nauplii.

\section{MATERIALS AND METHODS}

Zooplankton was collected weekly at a fixed station in coastal waters off Roscoff (western English Channel) during 1993, by gently towing a $500 \mu \mathrm{m}$ mesh net obliquely from $10 \mathrm{~m}$ to the surface. Samples were kept in an insulated box until they reached the laboratory, usually 1 or $2 \mathrm{~h}$ after collection.

Following a standardized 'egg incubation method' described by Laabir et al. (1995), 5 ripe Calanus helgolandicus females were placed in each of 6 incubators containing $1 \mathrm{l}$ unfiltered sea water and equipped with a $300 \mu \mathrm{m}$ sieve partition to prevent cannibalism; eggs were collected at the end of a $24 \mathrm{~h}$ incubation period.

Hatching success was determined by incubating freshly spawned eggs in crystallizing dishes containing 2 to $4 \mathrm{ml}$ of $0.22 \mu \mathrm{m}$ filtered sea water for a period $<72 \mathrm{~h}$, depending on the temperature. Laboratory experiments were run at 11 to $16 \pm 0.5^{\circ} \mathrm{C}$ and on a natural light cycle, corresponding to those occurring in situ at the time of capture. Abnormal embryonic development was observed microscopically. Details are reported by Poulet et al. (1995b).

Samples of chl a (used as a food index) were collected weekly on GFF filters in duplicates and analyzed using a 'Turner design' fluorimeter and Lorenzen's (1966) equations. These samples were collected at the same time and site as zooplankton, at the $5 \mathrm{~m}$ depth.

At the end of the incubations, faecal pellets $>20$ to 50 per sample) were pipetted and placed on a $0.2 \mu \mathrm{m}$ Nuclepore filter (13 $\mathrm{mm}$ in diameter). Duplicate samples of faecal pellets were stored at $-30^{\circ} \mathrm{C}$ prior to scanning electron microscope (SEM) analysis. Before SEM, the pellets were gently squashed and put through an ethanol dehydration series $(50,70,85,95$, and $100 \%$ ), critical-point dried, and coated with gold (Turner 1984b). Faecal pellet contents were examined with a Jeol JSM-5200 SEM with the upper detector set at $20 \mathrm{kV}$.

To simplify the description of the faecal pellet contents, only 3 major groups of particles were monitored, including diatoms, non-diatoms (dinoflagellates, coccolithophorids, silicoflagellates and crustacean remains), and unidentified debris and bacteria, on a relative scale of abundance (Urban et al. 1992). When a group represented $>60 \%$ of the total pellet content, it was recorded as 'abundant', whereas those comprised of between 20 and $60 \%$ were recorded 'common', and 'rare' when $<20 \%$. The pellet content was estimated as follows: each image viewed on the SEM monitor screen corresponding to a fraction of an entire pellet at the selected scale (i.e. $\times 3500$ ) was examined, and the proportion of each group of preys was quantified as equal to their relative surface on each frame. In each sample, 3 to 10 faecal pellets were screened. Estimates of the relative abundance of each group of food were made in triplicate on each sample. Black and white photographs (Kodak polaroid 200 ASA film) were taken of at least 2 to 5 different frames observed on the SEM screen, representative of each faecal pellet sample, depending on the diversity of food in pellets.

Laboratory feeding/spawning experiments consisted of monitoring for 1 to $2 \mathrm{wk}$ the daily hatching success of eggs spawned by 10 females placed in crystallizing dishes containing $200 \mathrm{ml}$ of $0.22 \mu \mathrm{m}$ filtered sea water enriched with $50 \mathrm{ml}$ of dense phytoplankton cultures. In 2 parallel series of experiments, 3 replicate batches of 10 females each were fed the diatom Phaeodactylum tricornutum given in excess concentrations, ranging from 15 to $30 \times 10^{4}$ cells ml ${ }^{-1}$ in one series and from 3 to $6 \times 10^{5}$ cells $\mathrm{ml}^{-1}$ in the other series. In another experiment, triplicate batches of 10 females each were first fed $P$. tricornutum ( 4 to $7 \times 10^{5}$ cells $\mathrm{ml}^{-1}$ ) for $7 \mathrm{~d}$ and then the dinoflagellate Prorocentrum minimum 10.7 to $1.6 \times 10^{4}$ cells $\mathrm{ml}^{-1}$ ) for another $11 \mathrm{~d}$. Food was resus-

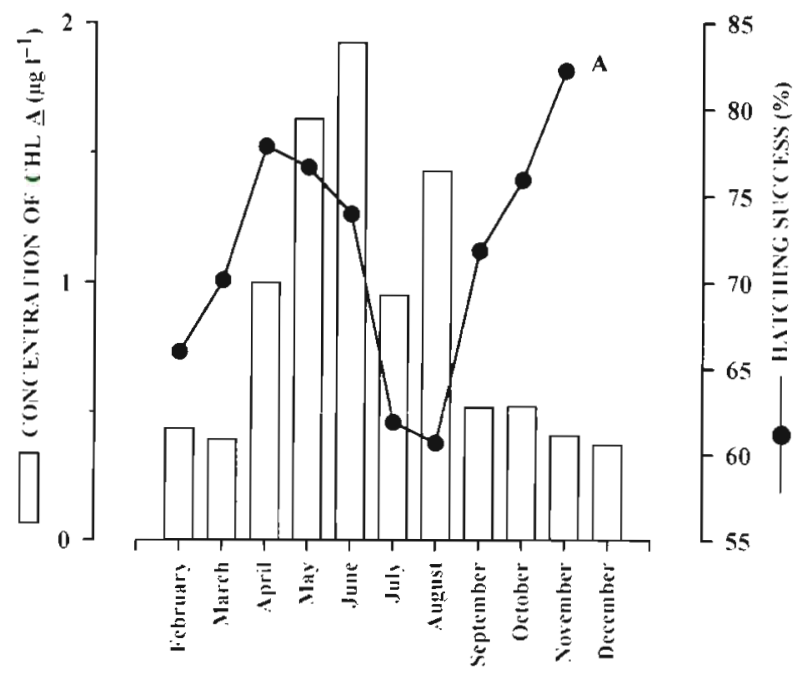

Fig. 1. Calanus helgolandicus. Variations of the mean monthly $\mathrm{chl}$ a concentration at $5 \mathrm{~m}$ depth in the western English Channel off the coast of Roscoff, France, in 1993. Each mean corresponds with 4 to 5 weekly observations. (A) Mean monthly values of the hatching success of eggs, showing the mismatch with chl a concentration 
pended by stirring 5 times $\mathrm{d}^{-1}$. Every $24 \mathrm{~h}$, copepods were removed and placed in new incubators with fresh media. Eggs were transferred to dishes containing 2 to $4 \mathrm{ml}$ filtered sea water, and incubated for $<72 \mathrm{~h}$ to estimate hatching rate (Laabir et al. 1995). P. tricornutum was grown in $\mathrm{f} / 2$ medium and P. minimum in $\mathrm{K}$ medium, both at $17^{\circ} \mathrm{C}$ and on a $12 \mathrm{~L}\left(200 \mu \mathrm{E} \mathrm{m}^{-2}\right): 12 \mathrm{D}$ cycle, and provided to copepods in the exponential phase of growth.

\section{RESULTS}

\section{Seasonal variations of chlorophyll a and egg viability}

Chl a showed strong seasonal fluctuations with maximum mean abundance $(1.5$ to $2 \mu \mathrm{g}$ $\left.1^{-1}\right)$ in late spring. Mean concentrations remained high until August, then decreased sharply in autumn to reach minimum values $\left(<0.5 \mu \mathrm{g} \mathrm{l}^{-1}\right)$ in winter (Fig. 1). $\mathrm{Chl}$ a was measured in samples collected at $5 \mathrm{~m}$ depth, which was representative of the concentration in the water column (i.e. $30 \mathrm{~m}$ deep on the sampling site), since coastal waters offshore Roscoff are characterized by permanently well-mixed conditions (i.e. Wafar et al. 1983).

Mean monthly hatching success showed periods of alternating low (early spring and midsummer) and high (late spring and fall) values (Fig. 1A). Mean annual egg production rate was $6.6 \pm 7.4$ eggs female $\mathrm{e}^{-1} \mathrm{~d}^{-1}$ (Laabir et al. unpubl.), whereas hatching success was only $70 \pm 20 \%$ of the total egg production. On a weekly basis, hatching success was highly variable, showing an amplitude of $60 \%$ variation over the year. The lowest values ( $<50 \%)$ were observed in March, April, July, August, and September, whereas they were close to or above the annual mean the rest of the year (Fig. 2).

There was no significant correlation (Eq. 1) between egg viability $\left(Y_{1}\right)$ and chl a $\left(X_{1}\right): Y_{1}=-1.12 X_{1}+72.73$; $\mathrm{r}=0.09 ; \mathrm{n}=10 ; \mathrm{p}>0.1$. A positive, significant correlation (Eq. 2) was found between fecundity $\left(Y_{2}\right)$ and chl a $\left.\left(X_{1}\right): Y_{2}=10.22 X_{1}-2.17 ; \mathrm{r}=0.92 ; \mathrm{n}=11 ; \mathrm{p}<0.001\right)$.

At times, in June, July and August, 50 to $80 \%$ of the eggs spawned by wild females did not hatch and showed strong morphological anomalies, as described by Poulet et al. (1995b). The nauplii that did hatch (20 to $50 \%$ ) were abnormal, characterized by asymmetrical, unsegmented appendages, a deformed body, and reduction of the number and length of the setae (Poulet et al. 1995b). These larvae died quickly after hatching, or were too weak to complete hatching. Sim- ilar anomalies were observed all year round, but were less frequent during fall and winter, compared to spring and summer, when diatom remains were much more abundant in faecal pellets.

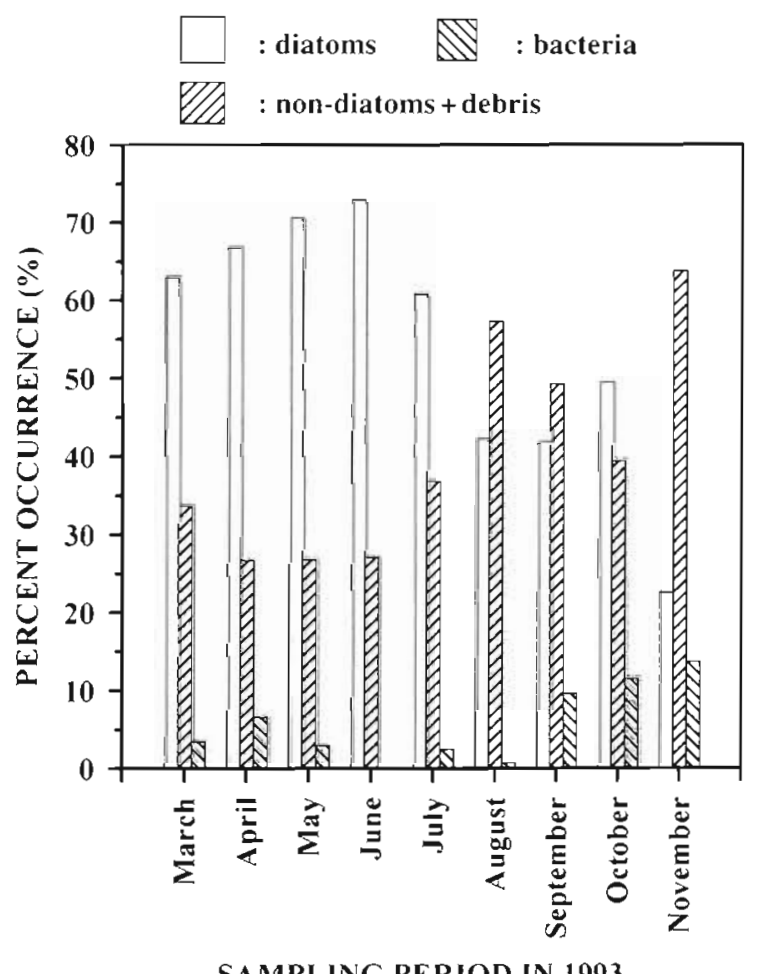

Fig. 3. Calanus helgolandicus. Histograms of the relative proportions of diatoms, non-diatoms plus debris and bacteria estimated in the faecal pellets of wild females. Each bar corresponds to the mean of at least 3 selected samples per month 
Seasonal variation of Calanus helgolandicus faecal pellet contents

The food ingested by Calanus helgolandicus in these coastal waters varied seasonally (Fig. 3). All year round, faecal pellets contained broken diatom frustules. The proportion of diatoms exceeded $60 \%$ from March to late July, and were identified as Thalassiothrix sp., Minidiscus sp., Rhizosolenia sp., Fragilariopsis sp. and Chaetoceros sp. (Fig. 4). From
August to November, the proportion of diatoms in the faecal pellets decreased and remained around $40 \%$ (Figs. $3 \& 5 \mathrm{~A}-\mathrm{C}$ ). The proportion of bacteria increased, reaching about $10 \%$ of the total content of faecal pellets in October and November. Most of the year, the non-diatom remnants (Fig. 6A-F), included silicoflagellates, dinoflagellates, coccolithophorids and crustacean remains. They were $<40 \%$ from March to July, but reached up to $60 \%$ the rest of the year (Fig. 3)
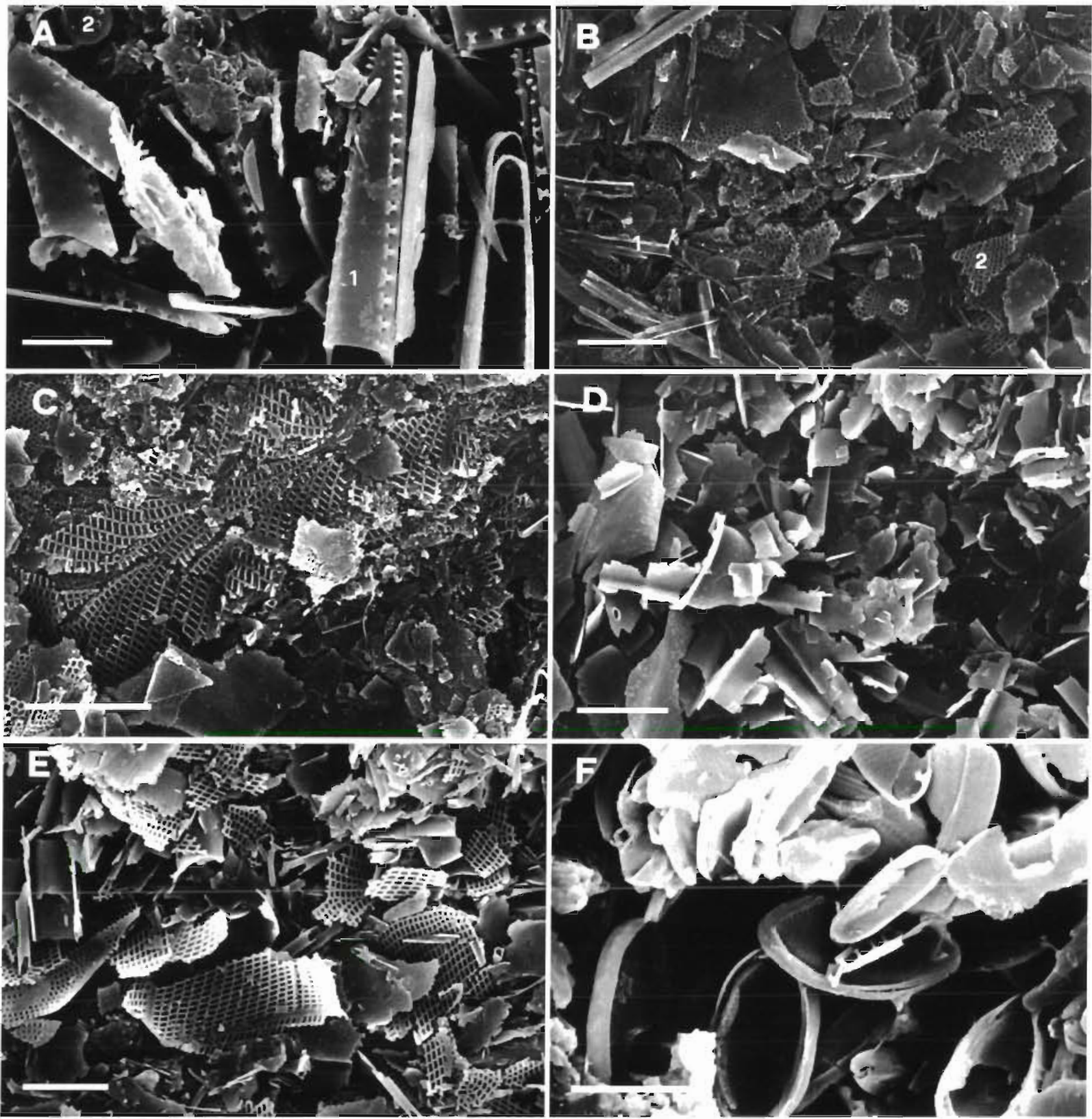

Fig. 4. Calanus helgolandicus. Representative SEM photographs of the faecal pellet contents of wild females from March to July 1993. Date of samples and dominant remains: (A) 9 March (1. Thalassiothrix sp., 2: Minidiscus sp.), (B) 4 May (1: setae of Chaetoceros sp., 2: Rhizosolenia sp.); (C) 23 June (Rhizosolenia sp.); (D) 23 June (fragments of unidentified diatoms); (E) 6 July (Rhizosolenia sp.): (F) 27 July (Fragilariopsis sp.). Scale bars $=5 \mu \mathrm{m}$ 


\section{Laboratory feeding experiments}

In a series of laboratory experiments, Calanus helgolandicus females were first fed the diatom Phaeodactylum tricornutum for $7 \mathrm{~d}$, and then the dinoflagellate

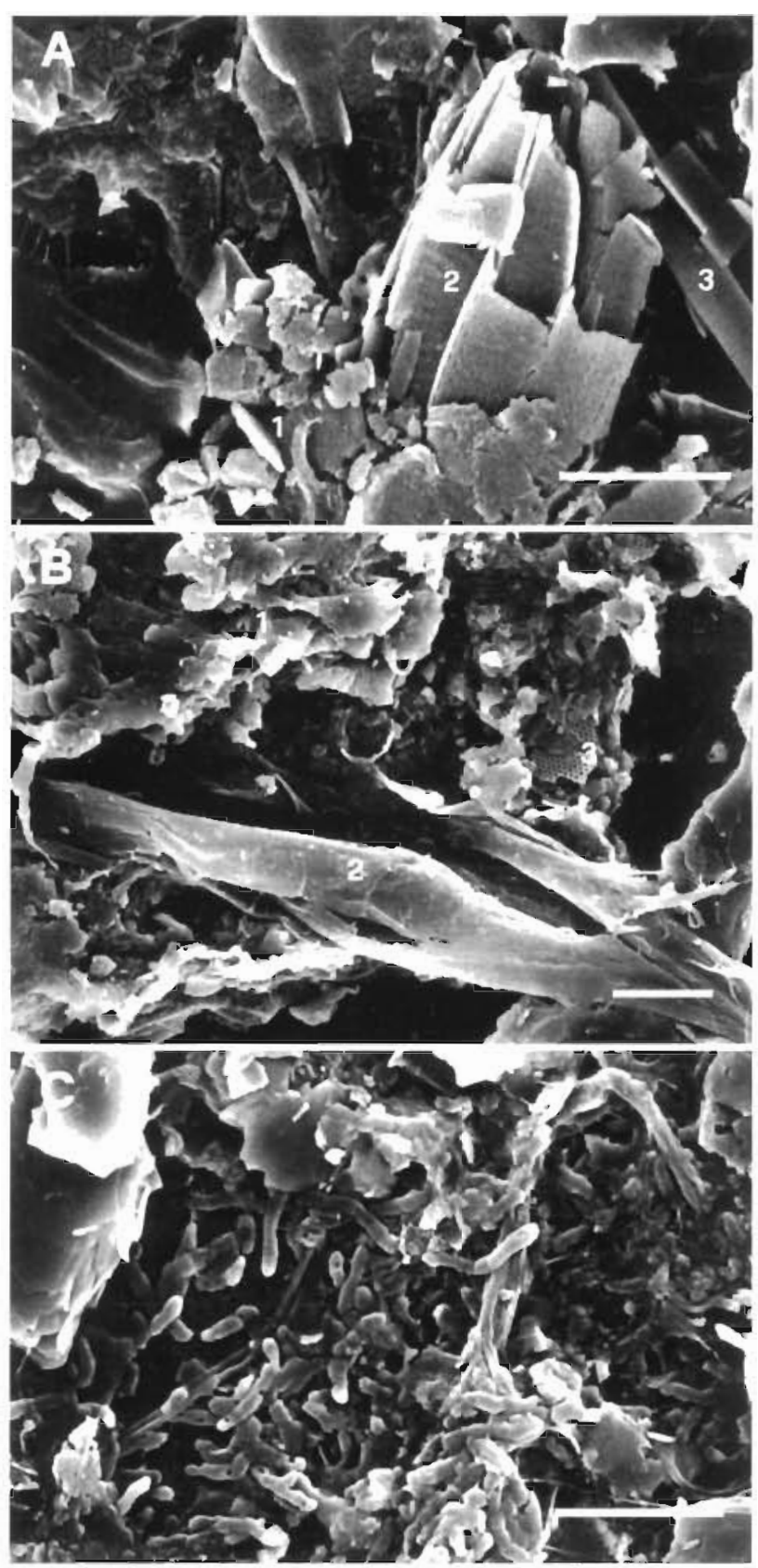

Fig. 5. Calanus helgolandicus. Representative SEM photographs of the faecal pellet contents of wild females from August to November 1993. Date of samples and most abundant food components: (A) 24 August (1. diatom remains, 2: unidentified pennate diatoms, 3: unidentified centric diatom); (B) 20 September (1: non-diatom debris, 2: crustacean remains, 3: Rhizosolenia sp.); (C) 11 October (bacteria). Scale bars $=5 \mu \mathrm{m}$
Prorocentrum minimum for the following $11 \mathrm{~d}$. Hatching success decreased drastically and reached $0 \%$ in $6 \mathrm{~d}$ with the diatom diet. When the diatom was substituted with the dinoflagellate diet, egg viability remained $0 \%$ for $3 \mathrm{~d}$ and then increased sharply, reaching $75 \%$ in only $4 \mathrm{~d}$. Egg viability then remained $>80 \%$ until the end of the incubation period (Fig. 7).

In another series of experiments, the diatom Phaeodactylum tricornutum was provided to Calanus helgolandicus females at 2 different concentrations. The results in Fig. 8 show 2 different patterns. At the lowest food concentration (Fig. 8A), hatching success varied with time, alternating between low and high values during the first week, and then decreased sharply to $0 \%$ after Day 13. On the contrary, at the higher food concentration (Fig. 8B), there was a sharp decrease in hatching success after Day 3, reaching $0 \%$ after $7 \mathrm{~d}$ from the start of incubations.

\section{DISCUSSION}

Estimates of 'natural mortality' (Ianora et al. 1992, Ianora \& Poulet 1993, Poulet et al. 1995a and present work) and of mortality due to other causes (see review by Peterson \& Kimmerer 1994) during the early phases of life of copepods are rare, despite the importance of this parameter in population dynamics studies. In previous reports (Landry 1978, Mullin 1988, Kiørboe \& Nielsen 1994, Liang et al. 1994, Peterson \& Kimmerer 1994, Uye \& Kayano 1994), in situ copepod mortality during the early life stages was mainly attributed to predation. More recent laboratory observations have revealed that total mortality in copepods may not be only due to predation, but also to several physiological causes (e.g. 'natural mortality') affecting embryonic and naupliar development (Williamson \& Butler 1987. Ianora \& Poulet 1993, Poulet et al. 1994, 1995b). In the coastal waters off Roscoff, the viability of Calanus helgolandicus eggs was not stable throughout the year 1993. In situ 'natural mortality' of $C$. helgolandicus for the egg to naupliar N1 stage varied between 5 and $80 \%$ of the daily egg production (Fig. 2).

One of the possible causes leading to such egg and naupliar mortality has been shown to be related to the composition of the food ingested by adult females in the laboratory (lanora \& Poulet 1993, Poulet et al. 1994, Miralto et al. 1995, Poulet et al. 1995b, Kleppel \& Burkart 1995). However, nothing is known of how this applies to in situ conditions. The question is: do diatoms arrest egg development of copepods in nature? Recent experiments have suggested the presence of inhibitors in diatoms, reducing or even arresting hatching success and embryonic development, and causing severe deformities in nauplii (Poulet et al. 

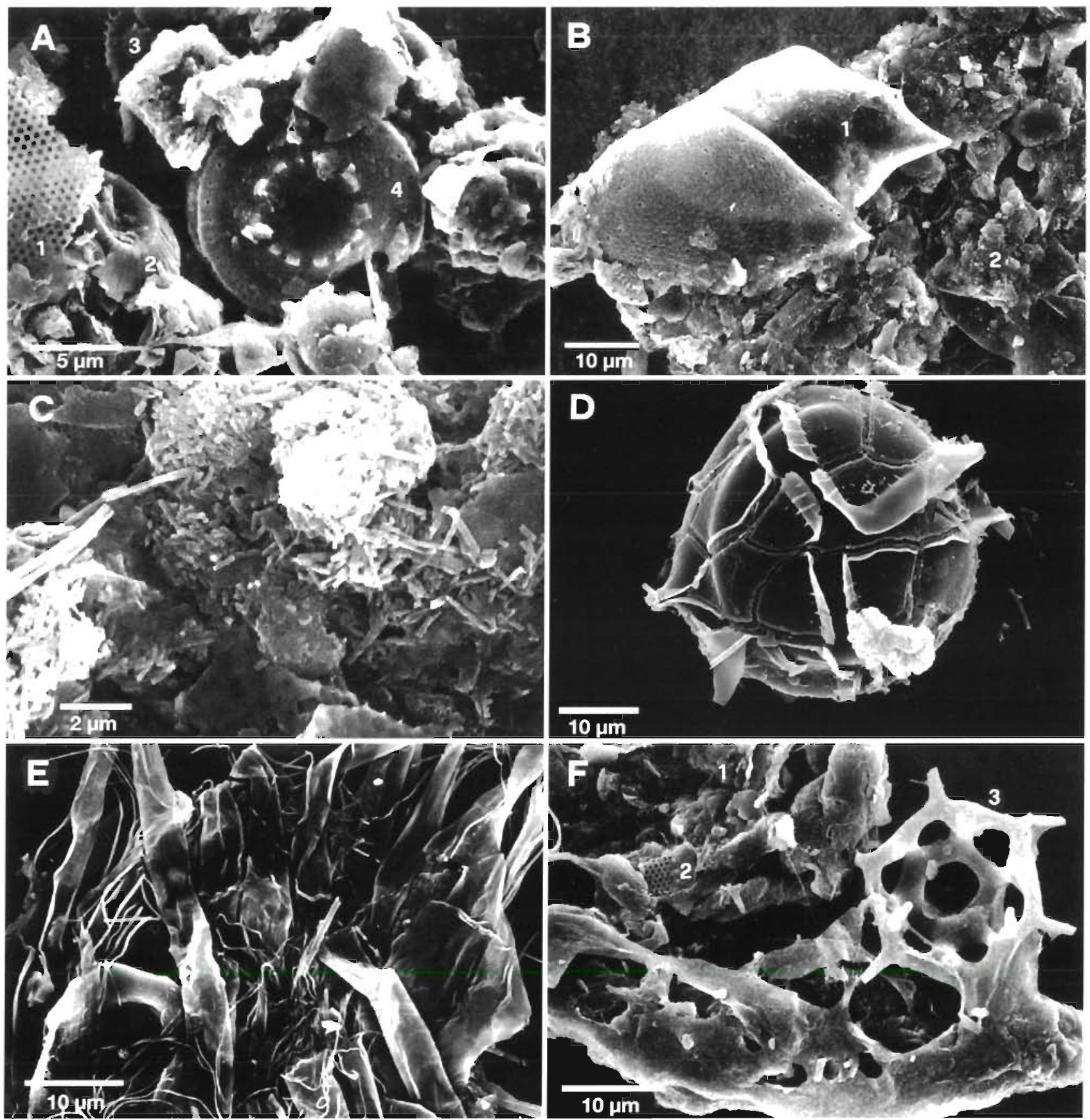

Fig. 6. Calanus helgolandicus. SEM photographs of the non-diatom food remains observed in faecal pellets collected in different seasons. Date of samples and food components: (A) 17 March (1: Rhizosolenia sp., 2: Coccolith of Coccolithopond sp., 3: non. diatom debris, 4: Paralia sp.); (B) 30 March (1. Prorocentrum micans, 2: non-diatom debris). (C) 8 April (bacteria); (D) 16 July (Protoperidinium sp.); (E) 21 July (crustacean remains); (F) 28 August (1 non-diatom debris, 2: Rhizosolenia sp., 3: Dictyocha speculum, 4: silicoflagellate). Scale bars as shown

1994, 1995b). Inhibition of egg development was neither due to the presence of bacteria (lanora et al. 1995b), nor to anoxia (Miralto et al. 1995). However, one of the problems with these experiments was related to the high concentration of algal cells used to feed the copepods, which were always much higher than phytoplankton blooms occurring in nature. For example, concentrations of diatom cells in the coastal waters off Roscoff were generally $<10^{2}$ to $10^{3}$ cells $\mathrm{ml}^{-1}$, even during the spring-summer diatom blooms (Grall 1972, Martin-Jézéquel 1983). The annual succession of phytoplankton species off Roscoff, described earlier 


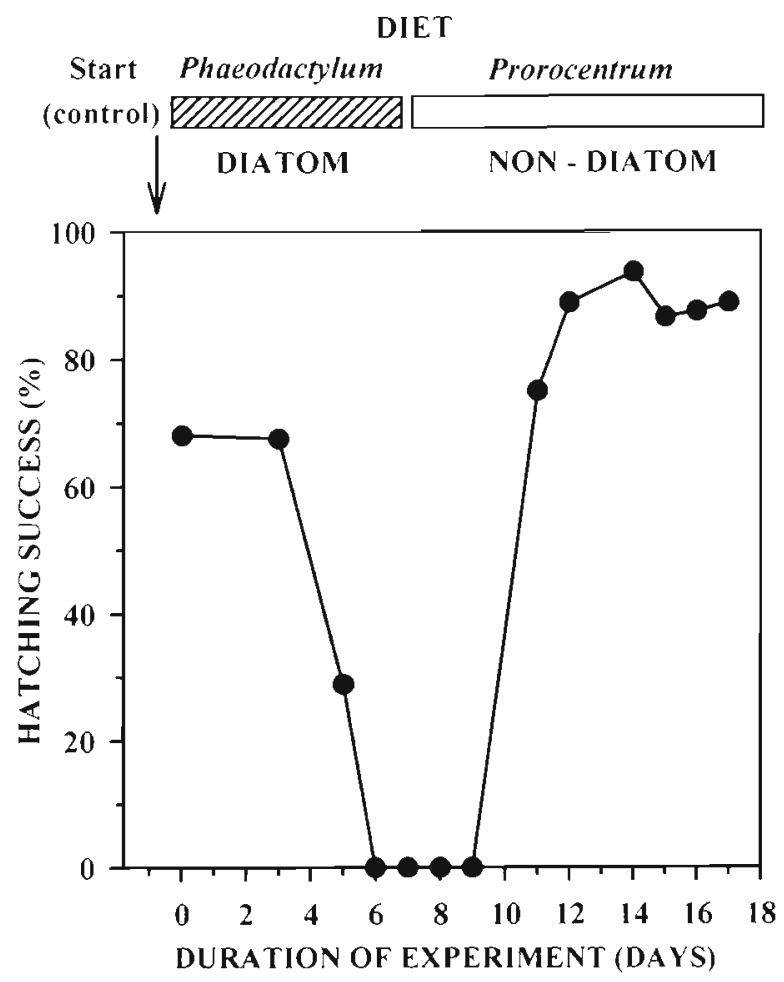

Fig. 7. Calanus helgolandicus. Variations of hatching success related to shifts in the diets. Eggs were spawned by females initially fed with the diatom Phaeodactylum tricornutum and then the dinoflagellate Prorocentrum minimum. Control (i.e. hatching success of normal eggs spawned by wild females) corresponds to Day 0 . Each data point corresponds to mean value of batch of $>30$ eggs

by Grall (1972) and Martin-Jézéquel (1983), has been almost similar over the years and is characterized by the presence and succession of dominant species of diatoms belonging to the following genera: Thalassiosira and Nitzschia in April, Chaetoceros and Rhizosolenia in May and June, and Chaetoceros in July. In contrast, diatom concentrations used in the laboratory to induce $100 \%$ inhibition of hatching were between $10^{4}$ and $10^{7}$ cells $\mathrm{ml}^{-1}$, which is 1 to 4 orders of magnitude higher than natural concentrations. Despite this large discrepancy, decrease of hatching success and similar embryonic and naupliar anomalies were observed both in the field and in the laboratory (Figs. 2, $7 \& 8$; Poulet et al. 1995b). Also, minimum values of hatching estimated in the field ranged between 20 and $50 \%$, even during diatom blooms (Fig. 2), but never reached $0 \%$ as in the laboratory (Figs. $7 \& 8$ ), which is consistent with the assumption that the higher the concentration of diatoms, the lower the hatching success (Fig. 7).

As hypothesized earlier, inhibition is possibly due to the accumulation of the inhibitors in the oocytes during vitellogenesis (Poulet et al. 1994). This hypothesis is supported by the results in Fig. 8. At the highest

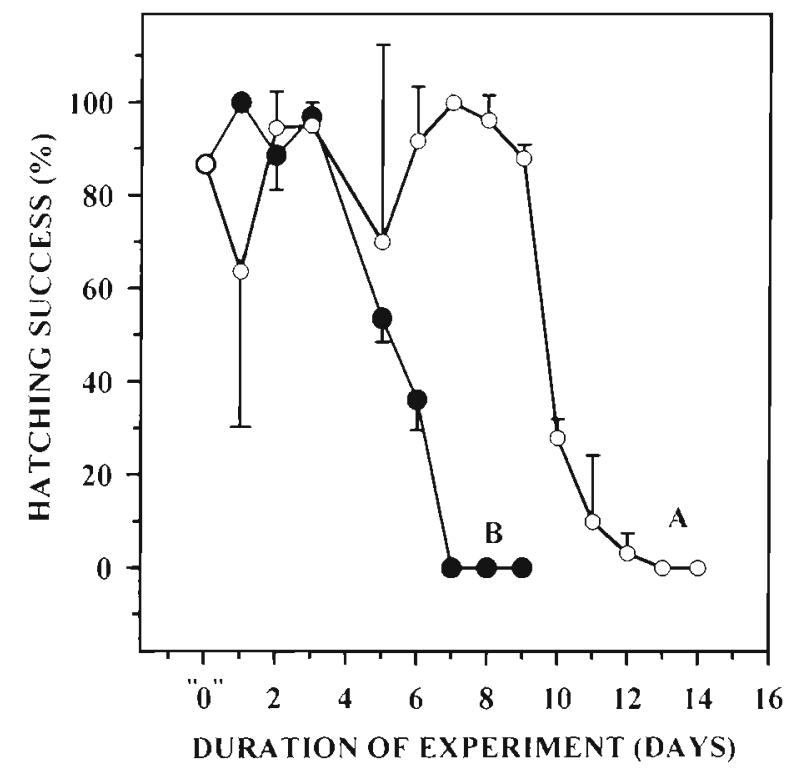

Fig. 8. Calanus helgolandicus. Diminution in hatching success as a function of food concentration. Eggs were spawned by female fed cultures of the diatom Phaeodactylum tricornutum at 2 different concentrations in the dishes: (A) 15 to $30 x$ $10^{4}$ cells $\mathrm{ml}^{-1}$; (B) 3 to $6 \times 10^{5}$ cells $\mathrm{ml}^{-1}$ Each data point corresponds to the mean and SD (bar) of 3 replicate batches of $n \geq 30$ eggs each. (O) Value at the start of incubation (control)

diatom concentrations $\left(10^{5}\right.$ cells $\mathrm{ml}^{-1}$; Fig, $\left.8 \mathrm{~B}\right)$, the lag time to reach $0 \%$ hatching success was only $7 \mathrm{~d}$. At lower concentrations $\left(10^{4}\right.$ cells $\mathrm{ml}^{-1}$; Fig. $\left.8 \mathrm{~A}\right)$, the lag time to reach $50 \%$ inhibition was $9 \mathrm{~d}$, whereas a longer delay $(14 \mathrm{~d})$ was necessary to reach $0 \%$ inhibition (Fig. 8). In the coastal waters off Roscoff, because of the much lower concentration of diatoms $\left(<10^{3}\right.$ cell $\left.\mathrm{ml}^{-1}\right)$, this lag could be even longer, probably on the order of $30 \mathrm{~d}$, considering the mismatch between the seasonal peak of chl $a$ and the minimum values for hatching success (Fig. 1). Also, the proportion of diatoms in faecal pellets was never $100 \%$, even during phytoplankton blooms (Fig. 3), implying that inhibition may be reduced. This lag is compatible with the reproductive life cycle of Calanus helgolandicus females, which is likely similar to $C$. finmarchicus ( $>1$ to $2 \mathrm{mo}$; Marshall \& Orr 1972), and with the occurrence of diatom blooms which generally last $>1 \mathrm{wk}$.

The results in Fig. 7 also suggest that inhibition of the hatching success of eggs by diatoms is reversible when a shift in food occurs, or when females feed on nondiatom diets over several days. Therefore, in analogy with these results, mixed diets in the field (Figs. 3, 4 \& 5) should also relax inhibition of diatoms and explain why in situ egg viability was so unstable and never reached $100 \%$ (Fig. 2), in contrast to our laboratory experiments, where copepods were placed under saturated food conditions, using unialgal cultures of diatoms. 
Does the cause and effect relationship found for diatoms and egg viability first demonstrated in the laboratory (Ianora \& Poulet 1993, Poulet et al. 1994) also occur in nature for Calanus helgolandicus (Poulet et al. 1995b)? The fact that there was no negative correlation between hatching success and concentration of chl a (Eq. 1; Ianora et al. 1992, Ianora \& Poulet 1993) apparently seems to contradict experimental studies. In fact, it does not, because chl a was always low in Roscoff waters (Fig. 1) and because Calanus did not only feed on diatoms (Figs. 3, 4, 5 \& 6). Failure to statistically establish a direct correlation with chl a (Eq. 1) may simply indicate that a longer lag time is necessary to allow for accumulation of diatom inhibitors during oogenesis at low concentrations, such as those prevailing in Roscoff waters in 1993. The results in Fig. 8 show that $100 \%$ inhibition occurs in 6 and $12 \mathrm{~d}$ following the start of feeding by $C$. helgolandicus females on Phaeodactylum tricornutum cultures provided at concentrations of $10^{5}$ and $10^{4}$ cells $\mathrm{ml}^{-1}$, respectively. More recent data (Chaudron unpubl.) indicated that an even longer time lag (i.e. $20 \mathrm{~d})$ exists at lower concentrations $\left(10^{3}\right.$ cells $\left.\mathrm{ml}^{-1}\right)$. These results indicate that a lag mechanism in the field is not speculative. Moreover, anomalies observed in embryos and nauplii produced by wild females were the same as those induced in the laboratory (see Poulet et al. 1995b) and were more frequent during periods of high in situ concentration of chl a (Fig. 2). In analogy with our experimental results, we believe that the in situ inhibition of eggs and subsequent naupliar deformities were due to ingestion of diatoms by $C$. helgolandicus females. This conclusion is supported by the SEM seasonal examination of the faecal pellets produced by wild females and collected at the same time as the eggs. This technique was already used to show shifts in zooplankton feeding related to phytoplankton variability (Urban et al. 1992). Diatom remains were identified in faecal pellets all year round, but their relative proportion varied with time (Fig. 3). The highest proportions in faeces were observed at different times during spring and summer, coinciding with high variability in weekly hatching success. However, the lowest monthly values of hatching success occurred in July and August (Figs. 1 \& 2). This may be due to any of several reasons: first, the lag between ingestion of diatoms, accumulation of inhibitors and the reproductive response of females; second, eggs were spawned by different cohorts of females, monitored only once; third, all diatoms might not contain inhibitors; fourth, egg development is not arrested, or inhibition is lowered and detected only in abnormal nauplii, especially at low diatom concentrations ( $\leq 10^{3}$ cells $\mathrm{ml}^{-1}$; Poulet et al. 1994, 1995b). On the contrary, hatching success was generally higher from
September to November when both the relative proportion of diatoms in the faeces and in situ chl a were lower (Figs. 1, 2, 5 \& 6)

We hypothesise that inhibition of embryonic development might be a natural adaptation of diatoms against their predators, reducing reproductive effort and thereby lowering population densities (Poulet et al. 1994). This mechanism operates fully (i.e. 100\% inhibition) at a diatom concentration threshold well above those occurring in Roscoff, which were always very low compared to laboratory conditions; and thus required a longer time for the accumulation of inhibitors in gonads compatible with stronger inhibition. Deleterious effects could also be reduced simply by shifting the diet from diatoms to non-diatom species (Fig. 7), or by diversifying the diets (Figs. 2, 5 \& 6). These processes may relax inhibition, keeping average hatching success around $70 \%$ in nature. However, at times during spring-summer phytoplankton blooms, egg mortality was $80 \%$, showing the inevitable impact of unknown factors. Obviously, this type of mortality is not due to predation. In addition to several potential factors affecting hatching success (e.g virus infection, food limitation, disease, genetics, age of females) we suggest another inhibition of embryonic development of female offspring, following feeding on diatoms. First, unstable hatching success coincided both with periods of diatom blooms and their maximum occurrence in faecal pellets. Second, anomalies in nature ressembled those induced in the laboratory. Third, the variable lag time reflected duration of feeding, concentration of diatoms and their cumulative effects on egg viability (e.g. Fig. 8). Although our combined field and laboratory results have explored a possible link between diatoms and egg viability, and because the in situ situation is extremely complex, our hypothesis does not exclude other factors (i.e. Peterson \& Kimmerer 1994) that could also lead to a reduction of copepod egg viability

Acknowledgements. It is a pleasure to thank Dr D. Marmo for identifying phytoplankton in faecal pellet samples. We also thank Dr R. Williams for examining the manuscript. Anonymous referees' suggestions are deeply appreciated.

\section{LITERATURE CITED}

Cushing DH (1975) Marine ecology and fisheries. Cambridge University Press, Cambridge

Grall JR (1972) Recherches quantitatives sur la production primaire du phytoplancton dans les parages de Roscoff. Thése doct., Univ. Paris VI

Ianora A, Mazzocchi MG, Grottoli R (1992) Seasonal fluctuations in fecundity and hatching success in the planktonic copepod Centropages typicus. J Plankton Res 14:1483-1494

Ianora A, Poulet SA (1993) Egg viability in the copepod 
Temora stylifera. Limnol Oceanogr 38:1615-1626

Ianora A, Poulet SA, Miralto A (1995a) Inhibition of copepod egg viability by diatoms. Mar Biol 121:533-539

Ianora A, Poulet SA, Miralto A (1995b) The diatom Thalassiosira rotula affects reproductive success in the copepod Acartia clausi. Mar Biol (in press)

Kiørboe T, Nielsen TG (1994) Regulation of zooplankton biomass and reproduction in a temperate, coastal ecosystem. 1. Copepods. Limnol Oceanogr 39:493-507

Kleppel GS, Burkart CA (1995) Egg production and the nutritional environment of Acartia tonsa: the role of food quality in copepod nutrition. ICES J mar Sci 52:297-304

Kjorsvik E, Mangor-Jensen A, Holmefjord I (1990) Egg quality in fishes. Adv mar Biol 26:71-113

Laabir M, Poulet SA, lanora A (1995) Measuring production and viability of eggs in Calanus helgolandicus. J Plankton Res 5:1125-1142

Landry MR (1978) Population dynamics and production of a planktonic marine copepod, Acartia clausii, in a small temperate lagoon on San Juan Island, Washington. Int Revue ges Hydrobiol 63:77-119

Liang D, Uye SI, Onbe T (1994) Production and loss of eggs in the calanoid copepod Centropages abdominalis Sato in Fukuyama Harbor, the inland Sea of Japan. Bull Plankton Soc Japan 41:131-142

Lorenzen CF (1966) A method for the continuous measurements of in vivo chlorophyll concentration. Deep Sea Res 13:223-227

Marshall SM. Orr AP (1952) On the biology of Calanus finmarchicus. VII. Factors affecting egg production. J mar biol Ass UK 30:527-547

Marshall SM, Orr AP (1972) The biology of a marine copepod. Springer-Verlag, Berlin

Martin-Jézéquel $V$ (1983) Facteurs hydrologiques et phytoplancton en baie de Morlaix (Manche Occidentale). Hydrobiologia 102:131-143

Miralto A, lanora A, Poulet SA (1995) Food type induces different reproduction responses in the copepod Centropages typicus. J Plankton Res 7:1521-1534

Mullin MM (1988) Production and distribution of nauplii and recruitment variability. Putting the pieces together. In: Toward a theory on biological-physical interactions in the world ocean. Kluwer Academic Publishers, Dordrecht, $p$ $297-320$

Paffenhöfer GA (1975) Cultivation of Calanus helgolandicus under controlled conditions. Helgoländer wiss Meeresunters 20:346-359

Parrish KK, Wilson DF (1978) Fecundity studies on Acartia

This article was submitted to the editor tonsa (Copepoda: Calanoida) in standardized culture. Mar Biol 46:65-81

Pepin P, Myers RA (1991) Significance of egg and larval size recruitment variability of temperate fish. Can $J$ Fish aquat Sci 48:1820-1828

Peterson WT, Kimmerer WJ (1994) Processes controlling recruitment of the marine calanoid Temora longicornus in Long Island Sound: egg production, egg mortality, and cohort survival rates. Limnol Oceanogr 39:1594-1605

Poulet SA, Ianora A, Laabir M. Klein Breteler WCM (1995a) Towards the measurement of secondary production and recruitment in copepods. ICES J mar Sci 52:359-368

Poulet SA, lanora A, Miralto A, Meijer A (1994) Do diatoms arrest embryonic development in copepods? Mar Ecol Prog Ser 111:79-86

Poulet SA, Laabir M, Ianora A, Miralto A (1995b) Reproductive response of Calanus helgolandicus. I. Abnormal embryonic and naupliar development. Mar Ecol Prog Ser 129:85-95

Tester PA, Turner JT (1990) How long does it take copepods to make eggs? J exp mar Biol Ecol 141:169-182

Turner JT (1984a) The feeding ecology of some zooplankters that are important prey items of larval fish. NOAA TechniCal Report NMFS 7, Washington, DC, p 1-28

Turner JT (1984b) Zooplankton feeding ecology: contents of fecal pellets of the copepods Eucalanus pileatus and Paracalanus quasimodo from the continental shelfwaters of the Gulf of Mexico. Mar Ecol Prog Ser 15:27-46

Urban JL, McKenzie CH, Deibel D (1992) Seasonal differences in the content of Oikopleura vanhoeffeni and Calanus finmarchicus faecal pellets - illustrations of zooplankton food web shifts in coastal Newfoundland waters. Mar Ecol Prog Ser 84:255-264

Uye S, Kayano Y (1994) Predatory feeding behavior of tortanus (Copepoda: Calanoida): life-stage differences and the predation impact on small planktonic crustaceans. $J$ crust Biol 14:473-483

Wafar MVM, LeCorre P, Birrien JL (1983) Nutrients and primary production in permanently well-mixed temperate coastal waters. Estuar coast Shelf Sci 17:431-446

Watras CJ, Haney JF (1980) Oscillations in the reproductive condition of Diaptomus leptopus (Copepoda: Calanoida) and their relation to rates of egg-clutch production. Oecologia 45:94-103

Williamson CE, Butler NM (1987) Temperature, food and mate limitation of copepod reproductive strategies: separating the effects of multiple hypotheses. J Plankton Res $9: 821-836$

Manuscript first received: January 2, 1995

Revised version accepted: May 16, 1995 